\title{
The shallow-water Asellota (Crustacea: Isopoda) from the Beagle Channel: Preliminary taxonomic and zoogeographical results*
}

\author{
BRENDA LÍA DOTI ${ }^{1}$, DANIEL ROCCATAGLIATA ${ }^{1}$ and DIEGO GABRIEL ZELAYA ${ }^{2}$ \\ ${ }^{1}$ Departamento de Biodiversidad y Biología Experimental, Facultad de Ciencias Exactas y Naturales, Universidad de \\ Buenos Aires, Ciudad Universitaria, C1428EHA, Buenos Aires, Argentina. E-mail: bdoti@bg.fcen.uba.ar \\ ${ }^{2}$ Museo de La Plata, Paseo del Bosque s/n, (1900) La Plata, Provincia de Buenos Aires, Argentina.
}

\begin{abstract}
SUMMARY: The shallow-water Asellota from the Beagle Channel were investigated, based on material collected at four localities in 2001-2002. A total of 3,124 asellotes were sorted, and three new species and 12 new records of distribution were reported. The Paramunnidae showed the highest species diversity and abundance ( 11 species and 1,463 specimens). The present research raises the number of species known from the Beagle Channel to 23; of these, 16 were previously reported from the Magellan Straits, representing 69\% of similarity. Based on the present results and published data, the faunistic affinities for the shallow-water Asellota was 30\% between the Magellan region and the Scotia Arc, and 26\% between the Magellan region and the Antarctic Peninsula.
\end{abstract}

Keywords: Asellota, Isopoda, diversity, Beagle Channel, Magellan region.

RESUMEN: Asellota (Crustacea: Isopoda) de aguas someras del Canal Beagle: Primeros resultados taxonómiCOS Y BIOGEOGRÁfICOS. - Se estudiaron los isópodos Asellota colectados en cuatro localidades de aguas poco profundas del Canal Beagle en el 2001 y 2002. Se obtuvo un total de 3.124 ejemplares, se identificaron 3 especies inéditas y se dieron a conocer 12 registros nuevos de distribución. Paramunnidae fue la familia con mayor diversidad específica y abundancia (11 especies y 1.463 individuos). En el presente trabajo se elevó a 23 el número de especies conocidas para el Canal Beagle, 16 de las cuales son también conocidas del Estrecho de Magallanes (69\% de similitud). A partir de los resultados del presente trabajo y datos bibliográficos, las afinidades faunísticas para los Asellota de aguas poco profundas fueron de $30 \%$ entre la región magallánica y el Arco de Scotia; y de $26 \%$ entre la región magallánica y la Península Antártica.

Palabras clave: Asellota, Isopoda, diversidad, Canal Beagle, región magallánica.

\section{INTRODUCTION}

The Beagle Channel is a narrow, elongated sound located at the southern tip of South America. Brandt et al. (1997) stated that this channel is one of the key areas for taxonomic, ecological and biogeographic research, and they suggested that it should be investigated faunistically in more detail.

*Received May 10, 2004. Accepted April 21, 2005.
Many isopod Asellota have been reported from the Magellan region, mainly by Nordenstam (1933), Menzies (1962), Winkler and Brandt (1993) and Winkler (1994a). Despite this, only seven species are known from the Beagle Channel up to now (Monod, 1926; Nordenstam, 1933; Brandt, 1999).

The aims of this study are to describe the taxonomic composition and abundance of the shallowwater Asellota from the Beagle Channel, and to ana- 

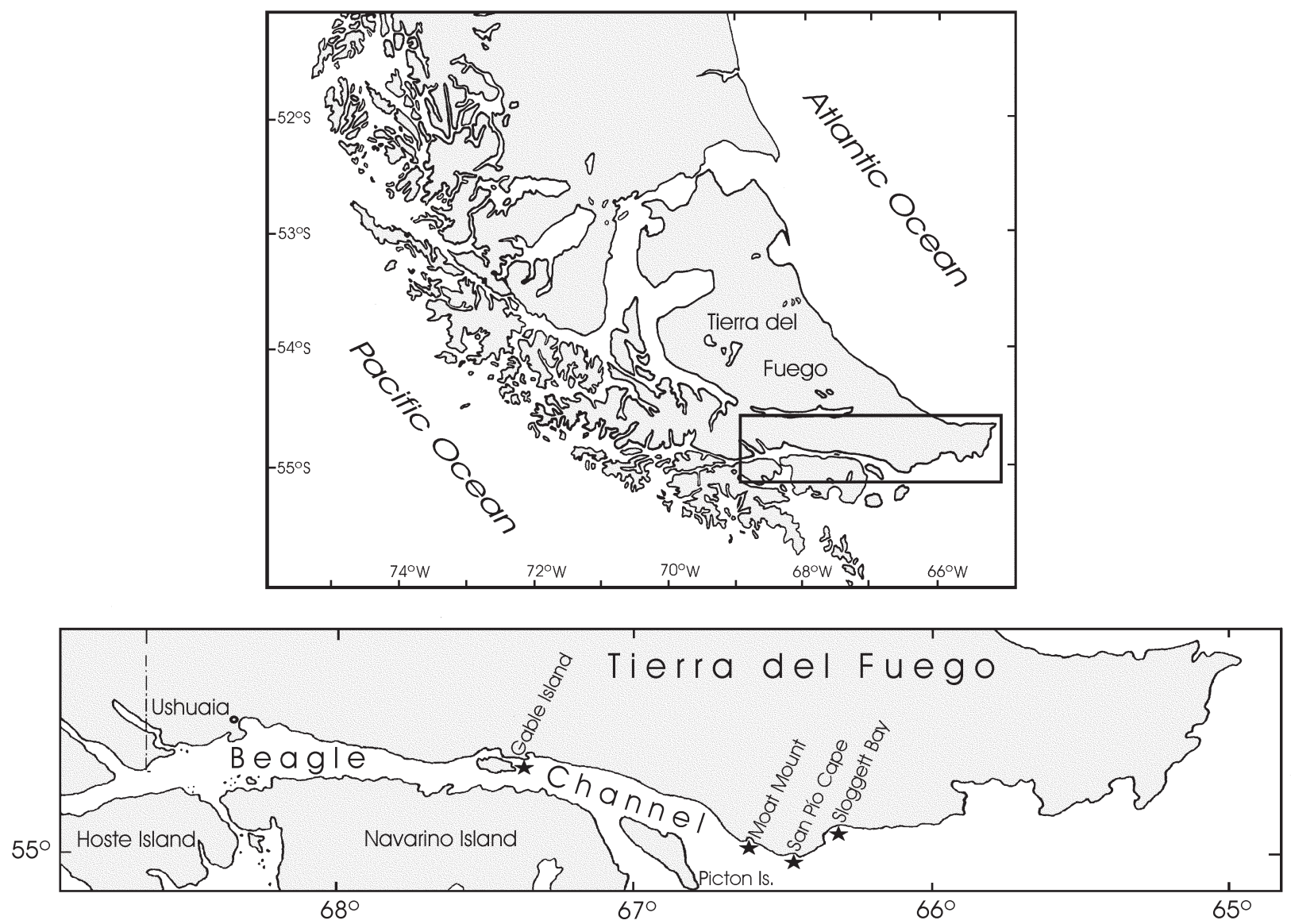

FIG. 1. - Locations of the sampling stations in the Beagle Channel.

lyze the faunistic affinities between this channel and the surrounding areas.

\section{MATERIAL AND METHODS}

The specimens studied were collected at four shallow-water localities, one in the Beagle Channel and the other three in front of its eastern mouth (Fig. 1, Table 1). For the sake of simplicity, all these localities are regarded as belonging to the Beagle Channel. Samples were dredged from the Argentine navy vessel "Alférez Sobral" at 15-35 m depth in February and May 2001 and September 2002. A $45 \times 50 \mathrm{~cm}$ trawl fitted with a net of $2 \mathrm{~mm}$ mesh size was used. The material collected was fixed in $10 \%$ buffered formaldehyde solution and transferred to $70 \%$ ethanol. The Asellota were picked from the bulk samples and identified to species (or genus) level.

In this contribution the Magellan region has been defined as the Patagonian shelf south of $41^{\circ} \mathrm{S}$ on both the Pacific and Atlantic coasts (including the
Malvinas/Falkland Islands); the Scotia Arc comprises the South Georgia, South Sandwich and South Orkney Islands; and the Antarctic Peninsula includes the South Shetland Islands.

The biogeographic analysis deals with the Asellota whose vertical distribution is restricted to depths $<200 \mathrm{~m}$ and those which were found at greater depths but also at $<200 \mathrm{~m}$. In order to facilitate comparisons between areas, a list of all the Asellota collected in shallow waters from the Magellan region (including our data from the Beagle Channel), the Scotia Arc and the Antarctic Peninsula is provided (Table 3). Papers which were consulted to prepare this list are mentioned in Winkler (1994b). Other papers utilised include the following:

TABLE 1. - Localities sampled in the Beagle Channel.

\begin{tabular}{lllll}
\hline Locality & Latitude & Longitude & Depth (m) & Date \\
\hline Gable Island & $5^{\circ} 54.4^{\circ} \mathrm{S}$ & $67^{\circ} 21.0^{\prime} \mathrm{W}$ & $15-20$ & 11 May 2001 \\
Moat Mount & $5^{\circ} 01.5^{\prime} \mathrm{S}$ & $66^{\circ} 41.7^{\prime} \mathrm{W}$ & $15-25$ & 09 Feb 2001 \\
San Pío Cape & $55^{\circ} 03.0^{\prime} \mathrm{S}$ & $66^{\circ} 37.0^{\prime} \mathrm{W}$ & $30-35$ & 29 Sep 2002 \\
Sloggett Bay & $5^{\circ} 00.0^{\prime} \mathrm{S}$ & $6^{\circ} 20.6^{\prime} \mathrm{W}$ & $15-30$ & 09 Feb 2001 \\
\hline
\end{tabular}


Kussakin (1965), Richardson and Hedgpeth (1977), Branch et al. (1991), Teodorczyk and Wägele (1994), Wilson and Wägele (1994), Serov and Wilson (1995), Mariani et al. (1996), Lorenti and Mariani (1997), Brandt (1999), Castelló (1999, 2004), Cariceo et al. (2002), Lörz and Brandt (2003), and Just and Wilson (2004). For the faunistic analysis, the localities marked with one or two asterisks and the specimens identified as "Paramunna cf. menziesi", "Sporonana sp.", "Austrofilius sp. A", "Ianiropsis sp. A", "Caecianiropsis cf. ectiformis", "Joeropsis sp. A", "Munna sp." and "Munna spec." in Table 3 were excluded. Junior synonyms in Table 3 are mentioned only when these names were used for specimens collected in the Magellan/Antarctic/Subantarctic areas. Affinities between areas were estimated using Simpson's Coefficient of Similarity $\left(\mathrm{C} / \mathrm{N}_{1} \times 100\right)$, where $\mathrm{C}=$ number of shared species and $\mathrm{N}_{1}=$ total number of species reported from the smaller of the two groups being compared (see Cheetham and Hazel, 1969). The term "diversity" refers to the total number of species, and the term "abundance" to the total number of specimens.

\section{RESULTS}

\section{Species composition and abundance in the Beagle Channel}

A total of 3,967 isopods were sorted, the Asellota being the dominant group (3,124 specimens), followed by the Sphaeromatidae (790 specimens), Rectarcturidae (17 specimens), Gnathiidae (15 specimens), Serolidae (14 specimens), Idoteidae (6 specimens) and Aegidae (1 specimen).

Among the Asellota, 25 species belonging to six families were identified (Table 2). Three of these species are new to science and 12 are new records for the Beagle Channel. All these new records belong to species formerly found in the Magellan Strait or other localities of the Magellan region (Table 3).

Of the three new species reported herein, two belong to the genus Austrosignum and one to the genus Paramunna. Since the Austrosignum/Munnogonium complex is under revision (Jean Just and George D.F. Wilson, pers. comms.), the inclusion of the new species identified as "Austrosignum n. sp.

TABLE 2. - Number of Asellota isopods collected in the Beagle Channel during this study. (*) First record for the area.

\begin{tabular}{|c|c|c|c|c|}
\hline & Gable Island & Moat Mount & San Pío Cape & Sloggett Bay \\
\hline \multicolumn{5}{|l|}{ Paramunnidae } \\
\hline Allorostrata ovalis Winkler, $1994 *$ & & & 6 & 6 \\
\hline Antennulosignum elegans Nordenstam, 1933 * & 4 & & & \\
\hline Austrosignum n. sp. 1 (unpublished) & & 3 & 30 & 401 \\
\hline Austrosignum n. sp. 2 (unpublished) & & & & 188 \\
\hline (?) Paramunna dentata Nordenstam, 1933 * (1) & & 2 & & 11 \\
\hline Paramunna integra Nordenstam, $1933 *$ & 5 & & 41 & 216 \\
\hline (?) Paramunna kerguelensis Vanhöffen, $1914 *$ (1) & & 1 & & \\
\hline (?) Paramunna menziesi Winkler, $1994 *(1)$ & & & 2 & 7 \\
\hline (?) Paramunna cf. menziesi ${ }^{(1)}$ & & & 69 & 178 \\
\hline Paramunna n. sp. (unpublished) & & & 15 & \\
\hline Pleurosignum magnum Vanhöffen, 1914 * & & & 11 & \\
\hline Sporonana sp. A & 171 & 3 & 92 & 1 \\
\hline \multicolumn{5}{|l|}{ Janiridae } \\
\hline Austrofilius furcatus Hodgson, 1910 & 101 & & 8 & \\
\hline Austrofilius sp. A & & 8 & & \\
\hline Caecianiropsis cf. ectiformis (Vanhöffen, 1914) & 3 & 1 & 1 & 1 \\
\hline Ianiropsis varians Winkler and Brandt, 1993 * & 1 & 95 & & 60 \\
\hline \multicolumn{5}{|l|}{ Iathrippa menziesi Sivertsen and Holthuis, 1980 (= } \\
\hline I. chilensis Menzies, 1962)* & 1 & 33 & 14 & 2 \\
\hline Neojaera antarctica (Pfeffer, 1887) & 41 & 10 & 127 & 10 \\
\hline \multicolumn{5}{|l|}{ Joeropsidae } \\
\hline \multicolumn{5}{|l|}{ Joeropsis curvicornis (Nicolet, 1849) $(=J}$. \\
\hline Joeropsis intermedius Nordenstam, 1933 & 192 & 18 & 187 & 17 \\
\hline Joeropsis sp. A & 124 & & 12 & 4 \\
\hline \multicolumn{5}{|l|}{ Munnidae } \\
\hline Munna gallardoi Winkler, 1992 * & & & 10 & \\
\hline Munna sp. & 11 & 1 & 233 & 1 \\
\hline \multicolumn{5}{|l|}{ Santiidae } \\
\hline \multirow{2}{*}{\multicolumn{5}{|c|}{$\begin{array}{l}\text { Santia compacta Sivertsen and Holthuis, } 1980 * \\
\text { Acanthaspidiidae }\end{array}$}} \\
\hline & & & & \\
\hline Ianthopsis laevis Menzies, $1962 *$ & & 1 & 25 & \\
\hline
\end{tabular}

(1) not in Paramunna after Just and Wilson (2004). 
TABle 3. - Asellota collected in the Magellan region, the Scotia Arc and the Antarctic Peninsula at depths $<200 \mathrm{~m}$. The species shared between the Beagle Channel and the Magellan Strait are in bold. Depths refer to the entire bathymetrical range of the species. BC, Beagle Channel; MS, Magellan Strait; OL, other localities.

\begin{tabular}{|c|c|c|c|c|c|c|}
\hline & $\mathrm{BC}$ & $\begin{array}{c}\text { Magellan Region } \\
\text { MS }\end{array}$ & OL & Scotia Arc & $\begin{array}{l}\text { Antarctic } \\
\text { Peninsula }\end{array}$ & Depths $(\mathrm{m})$ \\
\hline \multicolumn{7}{|l|}{ PARAMUNNIDAE } \\
\hline Austrosignum n. sp. 1 (unpublished) & + & & & & & $15-35$ \\
\hline Austrosignum n. sp. 2 (unpublished) & + & & & & & $15-30$ \\
\hline Paramunna n. sp. (unpublished) & + & & & & & $30-35$ \\
\hline (?) Paramunna cf. menziesi ${ }^{(1)}$ & + & & & & & $15-35$ \\
\hline Allorostrata ovalis Winkler, 1994 & + & + & & & & $12-35$ \\
\hline Paramunna integra sensu Winkler, 1994 (2) & + & + & & & & $10-70$ \\
\hline (?) Paramunna kerguelensis Vanhöffen, $1914^{(1)}$ & + & + & & & & $0-25$ \\
\hline (?) Paramunna menziesi Winkler, $1994^{(1)}$ & + & + & + & & & $9-35$ \\
\hline Pleurosignum chilense Menzies, 1962 & + & + & + & & & $0-50$ \\
\hline Antennulosignum elegans Nordenstam, 1933 & + & & + & & & $15-22$ \\
\hline (?) Paramunna dentata Nordenstam, $1933^{\text {(1) }}$ & + & & + & & & $15-30$ \\
\hline Sporonana sp. ${ }^{(3)}$ & + & + & & + & & $0-35$ \\
\hline Pleurosignum magnum Vanhöffen, 1914 & + & & + & & + & $22-385$ \\
\hline Allorostrata scutifrons Just and Wilson, 2004 & & + & & & & 9 \\
\hline Austrosignum dentatum Winkler, 1994 & & + & & & & 12 \\
\hline Austrosignum globifrons Menzies, 1962 & & + & & & & intertidal \\
\hline Magellianira serrata Winkler, 1994 & & + & & & & 10 \\
\hline Omonana brachycephala Just and Wilson, 2004 & & + & & & & 9 \\
\hline Omonana parasimplex (Winkler, 1994) & & + & & & & 9 \\
\hline (?) Paramunna magellanensis Winkler, $1994^{(1)}$ & & + & & & & $9-12$ \\
\hline (?) Paramunna patagoniensis Winkler, $1994^{(1)}$ & & + & & & & $12-21$ \\
\hline Munnogonium tillerae (Menzies and Barnard, 1959) & & + & & & + & $10-361$ \\
\hline Austrosignum falklandikum Nordenstam, 1933 & & & + & & & $22-150$ \\
\hline Austrosignum latifrons Menzies, 1962 & & & + & & & 100 \\
\hline Omonana simplex (Menzies, 1962) & & & + & & & 100 \\
\hline Paramunna integra Nordenstam, 1933 & & & + & & & $40-157$ \\
\hline $\begin{array}{l}\text { Austrosignum grande Hodgson, } 1910(=A . \\
\text { glaciale Hodgson, 1910) }\end{array}$ & & & + & + & + & $0-743$ \\
\hline Pleurosignum elongatum Vanhöffen, 1914 & & & + & & $*$ & $25-385$ \\
\hline Palanana serrata (Richardson, 1908) & & & ? & & + & $0-55$ \\
\hline Paramunna rostrata complex ${ }^{(4)}$ & & & & + & + & $6-107$ \\
\hline (?) Paramunna lunata Hale, $1937^{(1)}$ & & & & + & + & $3-32$ \\
\hline Coulmannia australis Hodgson, 1902 & & & & $*$ & + & $89-400$ \\
\hline Austrimunna antarctica Richardson, 1906 & & & & + & + & $12-107$ \\
\hline Austrosignum escanellae Castelló, 2004 & & & & & + & 45 \\
\hline Austrosignum incisum (Richardson, 1908) & & & & & + & $0-15$ \\
\hline Austrosignum spinosum Kussakin, 1982 & & & & & + & 17 \\
\hline Coulmannia ramosae Castelló, 2004 & & & & & + & 124 \\
\hline Harrietonana subtriangulata (Richardson, 1908) & & & & & + & 25 \\
\hline Palanana gaini (Richardson, 1913) & & & & & + & $1-6$ \\
\hline (?) Paramunna gaussi Vanhöffen, $1914^{(1)}$ & & & & & + & $45-385$ \\
\hline \multicolumn{7}{|l|}{ JANIRIDAE } \\
\hline Austrofilius sp. A & + & & & & & $15-25$ \\
\hline Ianiropsis sp. A & + & & & & & $15-25$ \\
\hline Caecianiropsis cf. ectiformis (Vanhöffen, 1914) & + & & & & & $15-35$ \\
\hline Ianiropsis varians Winkler and Brandt, 1993 & + & + & & & & $9-32$ \\
\hline $\begin{array}{l}\text { Iathrippa menziesi Sivertsen and Holthuis, } 1980 \text { (= } \\
\text { I. chilensis } \text { Menzies, 1962) }\end{array}$ & + & + & + & & & $5-300$ \\
\hline Iathrippa longicauda (Chilton, 1884) & + & + & + & $*$ & & $12-500$ \\
\hline $\begin{array}{l}\text { Iais pubescens (Dana, 1852) } \\
\text { hargeri Bovallius, } 1886)\end{array}$ & + & + & + & + & & $0-5$ \\
\hline Neojaera antarctica (Pfeffer, 1887) & + & + & + & + & + & $1-700$ \\
\hline Austrofilius furcatus Hodgson, 1910 & + & + & + & + & + & $0-190$ \\
\hline Iathrippa multidens Menzies, 1962 & & + & & & & intertidal \\
\hline Ianiropsis chilensis Menzies, 1962 & & + & + & & & $0-40$ \\
\hline Ianiropsis perplexus Menzies, 1962 & & & + & & & intertidal \\
\hline $\begin{array}{l}\text { Iathrippa sarsii (Pfeffer, 1887) (= Notasellus } \\
\quad \text { australis Hodgson, 1902) }\end{array}$ & & & $*$ & + & + & $0-700$ \\
\hline Iathrippa trilobatus (Richardson, 1910) & & & + & + & $*$ & $13-410$ \\
\hline Ectias turqueti Richardson, 1906 & & & & + & + & 6-126 \\
\hline Austrofilius serratus Vanhöffen, 1914 & & & & & ** & $170-385$ \\
\hline \multicolumn{7}{|l|}{ JOEROPSIDAE } \\
\hline Joeropsis sp. A & + & & & & & $15-35$ \\
\hline $\begin{array}{l}\text { Joeropsis curvicornis (Nicolet, 1849) }(=J . \\
\text { patagoniensis } \text { Richardson, 1909) }\end{array}$ & + & + & + & & & $0-641$ \\
\hline Joeropsis intermedius Nordenstam, 1933 & + & + & + & & $* *$ & $3-641$ \\
\hline Joeropsis bidens Menzies, 1962 & & & + & & & $0-300$ \\
\hline Joeropsis antarctica Menzies and Schultz, 1968 & & & & & + & $45-1408$ \\
\hline
\end{tabular}

162 B.L. DOTI et al. 
TABLE 3 (Cont.). - Asellota collected in the Magellan region, the Scotia Arc and the Antarctic Peninsula at depths $<200$ m. The species shared between the Beagle Channel and the Magellan Strait are in bold. Depths refer to the entire bathymetrical range of the species. BC, Beagle Channel; MS, Magellan Strait; OL, other localities.

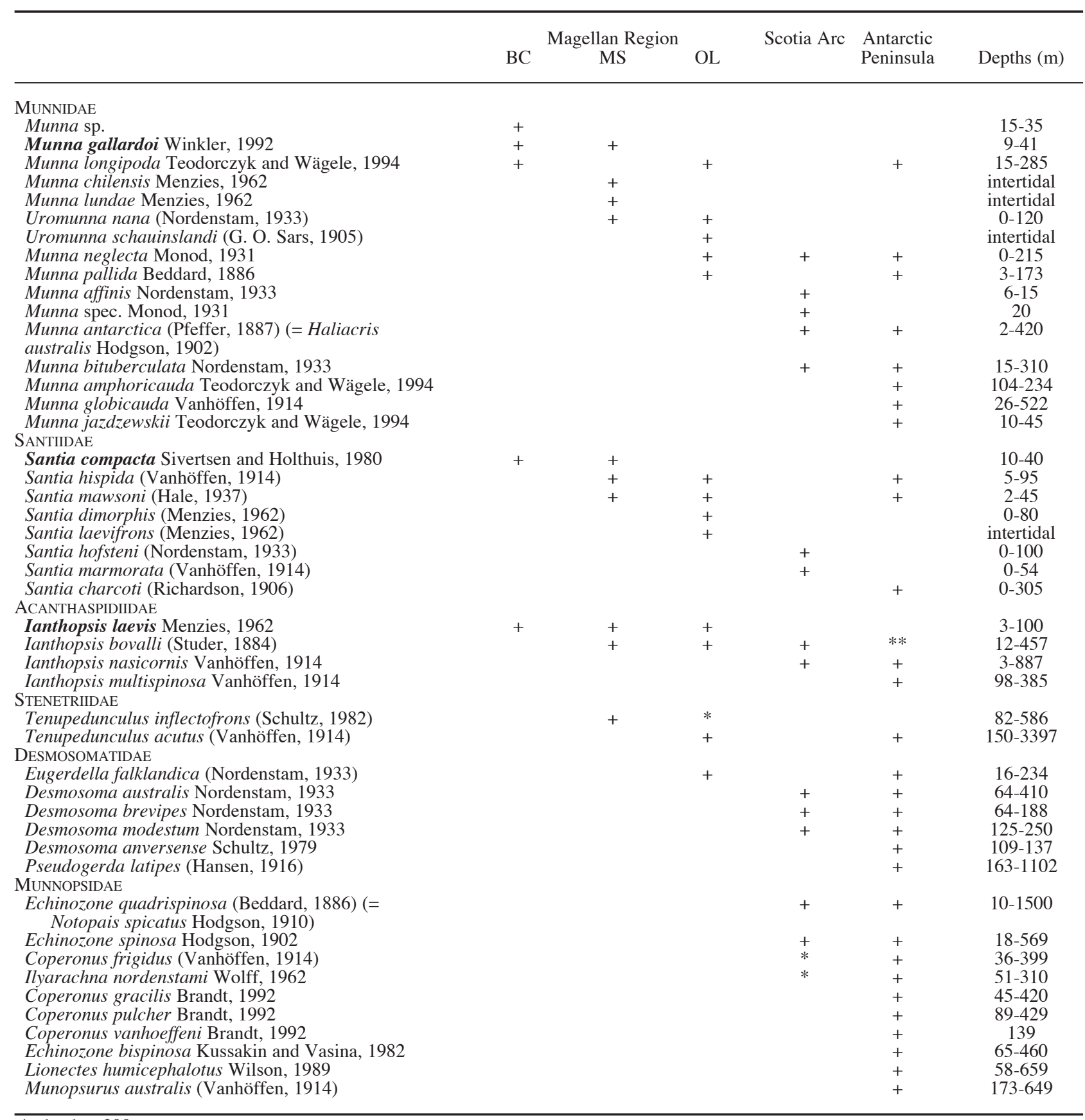

* depth $>200 \mathrm{~m}$.

** depth unknown.

(1) not in Paramunna after Just and Wilson (2004).

(2) includes Paramunna integra sensu Winkler (1994) and many specimens present in our samples.

(3) includes Paramunna subtriangulata sensu Monod (1926), Nordenstam (1933), Menzies (1962), Winkler (1994a), and many specimens present in our samples.

(4) includes Austrimunna rostrata sensu Richardson (1913) and Paramunna rostrata sensu Nordenstam (1933). Some of these specimens may belong to the genus Pagonana proposed by Just and Wilson (2004).

1" and "Austrosignum n. sp. 2" in Tables 2 and 3 should be taken as provisional.

At family level, the Paramunnidae showed the highest diversity (11 species) and abundance
(1,463 specimens). Janiridae was the second family in diversity (7 species) and Joeropsidae the second family in abundance (852 specimens) (Table 2). 


\section{Faunistic affinities between the Beagle Channel and the Magellan Straits}

Including the data herein reported, the number of shallow-water asellotes in the Beagle Channel and the Magellan Straits was 23 and 34 respectively (Table 3). Sixteen of the species of the Beagle Channel co-occur in the Magellan Straits, which represents $69 \%$ of similarity (Table 3 ).

The Beagle Channel and the Magellan Straits shared six of the eight families reported from the Magellan region: Paramunnidae, Janiridae, Joeropsidae, Munnidae, Santiidae and Acanthaspidiidae (Table 3). One species of Stenetriidae has been reported from the Magellan Straits but no specimens were found in our samples. No member of Desmosomatidae has been reported from the Magellan Straits, and our samples did not contain any species of this family either.

For both areas the Paramunnidae and Janiridae were the most diverse families (Table 3). For the Paramunnidae 11 species were found in the Beagle Channel and 14 in the Magellan Straits. Of these, only five species co-occur in both areas. For the Janiridae six species were found in the Beagle Channel and eight in the Magellan Straits, all the species recorded from the Beagle Channel being also present in the Magellan Straits.

\section{Faunistic affinities between the Magellan region and the Scotia Arc and the Antarctic Peninsula}

Table 3 lists all the Asellota recorded at depths < $200 \mathrm{~m}$ from the Magellan region, the Scotia Arc and the Antarctic Peninsula. Of the 89 species reported for the entire area, 58 were found in the Magellan region, 23 in the Scotia Arc, and 50 in the Antarctic Peninsula. The Magellan region shared 7 species with the Scotia Arc (30\% of similarity) and 13 species with the Antarctic Peninsula (26\% of similarity).

The Paramunnidae showed the highest diversity in the Magellan region and the Antarctic Peninsula, while the Janiridae was the most diverse family in the Scotia Arc (Table 3).

\section{DISCUSSION}

The examination of just a few samples yielded three new species and 12 new records for the Beagle Channel, which suggests that many species of Asellota still remain undiscovered in this coastal area.
Winkler (1994b) mentioned that the Paramunnidae was the most diverse family in the Magellan region, followed by the "Janiridae/Joeropsidae", a fact that is consistent with our results in the Beagle Channel.

Nordenstam (1933) erected the genus Antennulosignum (Paramunnidae) to include A. elegans from the Malvinas Islands. This species is reported herein for the second time after its original description (Table 2). Brandt (1999) described some specimens from the Beagle Channel as Pleurosignum chilense Menzies, 1962. However, it is likely that because of their peculiar antennule the specimens studied by Brandt belong to the genus Antennulosignum.

The genus Caecianiropsis (Janiridae) includes three species. Of these, only C. ectiformis (Vanhöffen, 1914) is found in the southern hemisphere. This species was previously known from the following Subantarctic islands: Kerguelen, St. Paul, and Marion/Prince Edward (Vanhöffen, 1914; Kensley, 1976; Branch et al., 1991). Our finding of $C$. cf. ectiformis in the Beagle Channel widely extends the range of distribution of the genus Caecianiropsis in the southern hemisphere.

The genus Munna (Munnidae) is well represented in the Magellan region (Winkler, 1994b), as well as in Antarctic and Subantarctic waters (Teodorczyk and Wägele, 1994). Although six species were reported from the Magellan region (Nordenstam, 1933; Menzies, 1962; Winkler, 1992, 1994b; Teodorczyk and Wägele, 1994; Lorenti and Mariani, 1997) only one, Munna gallardoi Winkler, 1992, was identified from the Beagle Channel (Table 3). Most probably, among the specimens herein reported as "Munna sp." more than one species were included, but the poor condition of the available material has prevented us from identifying them.

The family Santiidae has a pronounced southern distribution, and its species occur at depths of less than 100 m (Wolff, 1989). Five species of Santia have been reported from the Magellan region (Winkler, 1994b; Lorenti and Mariani, 1997); in contrast, only one has been found in the Beagle Channel so far (Table 3).

Two species belonging to the family Acanthaspidiidae have been recorded from the Magellan region. Ianthopsis laevis Menzies, 1962, endemic for this region, was recorded herein from the Beagle Channel. On the other hand, Ianthopsis bovallis (Studer, 1884) was not reported from the Beagle Channel, despite its wide distribution in the southern seas (see Winkler, 1994b; Lorenti and Mariani, 1997). 
The species of the genus Tenupedunculus (Stenetriidae) and those of the families Desmosomatidae and Munnopsidae are distributed mainly in deep-sea waters (Kussakin, 1973; Serov and Wilson, 1995). However, emergence has been postulated for many deep-sea Asellota, especially at higher latitudes (see Brandt et al., 2004). This could explain the larger number of species found in the Scotia Arc/Antarctic Peninsula in comparison with the Magellan region (Table 3). Although no species of the three families mentioned above have been recorded from the Beagle Channel, Eugerdella falklandica (Nordenstam, 1933) and some species of Tenupedunculus, a genus that is distributed from around the southern tip of South America to the Antarctic, are likely to be found in future surveys carried out in the Beagle Channel.

Menzies (1962) recorded four species from Chile, viz., Uromunna schauinslandi (G. O. Sars, 1905) near $41^{\circ} \mathrm{S}$, Joeropsis bidens Menzies, 1962 between 42 and $20^{\circ} \mathrm{S}$, Santia dimorphis (Menzies, 1962) near $44^{\circ} \mathrm{S}$ and Santia laevifrons (Menzies, 1962) between 44 and $32^{\circ} \mathrm{S}$. All these species were found slightly below $41^{\circ} \mathrm{S}$ and thus were listed in Table 3. Because zoogeographic regions cannot be neatly divided, the addition of these species to the Magellan fauna must be taken with caution.

Knowledge of the Magellan Asellota is still scarce and further taxonomic studies are strongly required. Although the results presented herein are preliminary, they will hopefully contribute to a better understanding of this faunal group.

\section{ACKNOWLEDGEMENTS}

The authors thank G.D.F. Wilson (Australian Museum, Sydney), J. Just (Museum of Tropical Queensland) and A. Brandt (Universität Hamburg), whose suggestions improved this paper; G. A. Lovrich (CADIC, Ushuaia) for providing field equipment and laboratory facilities; and M. Matesa and J. Amato, commanders-in-chief of the Base Naval Ushuaia, and the crew of the A.R.A. "Alférez Sobral" for their help with the collection of the samples. This study was partially supported by the Agencia Nacional de Promoción Científica y Tecnológica (PICT 11180), the Universidad de Buenos Aires (Grant X162), and the Consejo Nacional de Investigaciones Científicas y Técnicas (CONICET, Argentina).

\section{REFERENCES}

Branch, M.L., C.L. Griffiths, B. Kensley and J. Sieg. - 1991. The benthic Crustacea of Subantarctic Marion and Prince Edward Islands: Illustrated keys to the species and results of the 19821989 University of Cape Town Surveys. S. Afr. J. Antarct. Res., 21: 3-44.

Brandt, A. - 1999. Redescriptions of Paramunna lunata Hale, 1937 and Pleurosignum chilense Menzies, 1962 (Crustacea, Isopoda, Paramunnidae). Mitt. Hamb. Zool. Mus. Inst., 96: 129-139.

Brandt, A., K. Linse and U. Weber. - 1997. Abundance and diversity of peracarid taxa (Crustacea, Malacostraca) along a transect through the Beagle Channel, Patagonia. Polar Biol., 18: 83-90.

Brandt, A., W. Brökeland, S. Brix and M. Malyutina. - 2004. Diversity of Southern Ocean deep-sea Isopoda (Crustacea, Malacostraca) - a comparison with shelf data. Deep-Sea Res. II, 51: 1753-1768.

Cariceo, Y., E. Mutschke and C. Ríos. - 2002. Ensambles de Isopoda (Crustacea) en discos de fijación del alga Macrocystis pyrifera (C. Agardh) (Phaeophyta) en el Estrecho de Magallanes, Chile. Anales Instituto Patagonia. Serie Cs. Nat., 30: 83-94.

Castelló, J. - 1999. Taxonomic study of the isopod crustaceans from the Spanish expedition "Antártida 1986-11" in the Scotia Sea, South Atlantic. Sci. Mar., 63(Suppl. 1): 275-279.

Castelló, J. - 2004. Isopods (Crustacea, Isopoda) from the Spanish "Bentart-94/95" expeditions to the South Shetland Islands (subAntarctic). Polar Biol., 28: 1-14.

Cheetham, A.H. and J.E. Hazel. - 1969. Binary (presence-absence) similarity coefficients. J. Paleontol., 43: 1130-1136.

Just, J. and G.D.F. Wilson. - 2004. Revision of the Paramunna complex (Isopoda: Asellota: Paramunnidae). Invertebr. Taxon., 18: 377-466.

Kensley, B. - 1976. Isopodan and tanaidacean Crustacea from the southern Indian Ocean (Crustacea, Isopoda, Asellota). Ann. S. Afr. Mus., 69: 261-323.

Kussakin, O.G. - 1965. On the fauna of Desmosomatidae (Crustacea, Isopoda) of the far-eastern seas of the U.S.S.R. Akad. Nauk SSSR, Zool. Inst., Exploration of the fauna of the seas III (XI) Fauna Seas NW Pacific: 115-144. [in Russian].

Kussakin, O.G. - 1973. Peculiarities of the geographical and vertical distribution of marine isopods and the problem of deep-sea faunal origin. Mar. Biol., 23: 19-34.

Lorenti, M. and S. Mariani. - 1997. Isopod assemblages in the Straits of Magellan: structural and functional aspects. Polar Biol., 18: 254-259.

Lörz, A-N. and A. Brandt. - 2003. Diversity of Peracarida (Crustacea, Malacostraca) caught in a suprabenthic sampler. Antarct. Sci., 15: 433-438.

Mariani, S., M.C. Gambi, M. Lorenti and L. Mazzella. - 1996. Benthic populations of the soft bottoms in the Strait of Magellan (Southern America): Biodiversity, distribution and biogeography of polychaetes and crustacean isopods. Biol. Mar. Medit., 3(1): 155-158.

Menzies, R.J. - 1962. The zoogeography, ecology and systematics of the Chilean marine isopods. Lund Univ. Arsskr., N.F., Avd. 2, 57(11): 1-162.

Monod, Th. - 1926. Tanaidacés, isopodes et amphipodes. Rés. Voy. “Belgica” 1897-1899: 1-67.

Nordenstam, A. - 1933. Marine Isopoda of the families Serolidae, Idotheidae, Pseudidotheidae, Arcturidae, Parasellidae and Stenetriidae mainly from the South Atlantic. Further Zool. Res. Swed. Antarct. Exped. 1901-1903, 3: 1-284.

Richardson, M.D. and J.W. Hedgpeth. - 1977. Antarctic soft-bottom, macrobenthic community adaptations to a cold, stable, highly productive, glacially affected environment. In: G.A. Llano (ed.), Adaptations within Antarctic ecosystems. Proc. Third SCAR Symposium on Antarctic Biology, Smithsonian Institution, pp. 181-196. Gulf Publishing Co., Houston, Texas.

Serov, P.A. and G.D.F. Wilson. - 1995. A review of the Stenetriidae (Crustacea: Isopoda: Asellota). Rec. Aust. Mus., 47: 39-82.

Teodorczyk, W. and J.-W. Wägele. - 1994. On Antarctic species of the genus Munna Krøyer, 1839 (Crustacea, Isopoda, Asellota, Munnidae). Bull. Mus. Natl. Hist. Nat., Paris, 16(A1): 111-201.

Vanhöffen, E. - 1914. Die Isopoden der Deutschen Südpolar-Expedition 1901-1903. Dt. Südpolar-Exp. 1901-1903, 15, Zool. 7(4): 447-598.

Wilson, G.D.F. and J.-W. Wägele. - 1994. Review of the family 
Janiridae (Crustacea: Isopoda: Asellota). Invertebr. Taxon., 8: 683-747.

Winkler, H. - 1992. On two Magellanic Munnidae; a new species of Munna and Uromunna nana (Nordenstam, 1933) (Crustacea: Isopoda: Asellota). J. Nat. Hist., 26: 311-326.

Winkler, H. - 1994a. Paramunnidae (Crustacea: Isopoda: Asellota) from the Magellan Strait. Zool. J. Linn. Soc., 110: 243-296.

Winkler, H. - 1994b. Charakterisierung der Isopodenfauna (Crus- tacea, Malacostraca) des Scotia-Bogens aus biogeographischer Sicht: Ein multivariater Ansatz. Ber. Polarforsch., 139: 1-196.

Winkler, H. and A. Brandt. - 1993. Janiridae (Crustacea, Asellota) from the southern hemisphere: Ianiropsis varians $\mathrm{sp}$. n. and redescriptions of five little-known species. Zool. Scr., 22: 387-424.

Wolff, T. - 1989. The genera of Santiidae Kussakin, 1988, with the description of a new genus and species (Crustacea, Isopoda, Asellota). Steenstrupia, 15: 177-191. 